\title{
IMPLEMENTASI RIGGING PADA RAMBUT 3D
}

\author{
Muhammad Ichfan Askar ${ }^{1}$, Arief Setyanto ${ }^{2}$, Amir Fatah Sofyan ${ }^{3}$ \\ Magister of Informatics Engineering Universitas Amikom Yogyakarta ${ }^{1,2,3}$ \\ Yogyakarta, Indonesia \\ Email: icfan.1237@students.amikom.ac.id ${ }^{1}$, arief_s@amikom.ac.id ${ }^{2}$, amir@ amikom.ac.id ${ }^{3}$
}

\begin{abstract}
ABSTRAK
Animasi 3D adalah sebuah seni untuk dapat membuat dan menggerakan objek 3D, sehingga dapat menghasilkan suatu gerakan yang sesuai dengan keinginan pembuatnya. Dalam pembuatan animasi tersebut, dibutuhkan objet 3D dan juga Rigging. Adapun tahapan implementasi program yaitu tahap pertama adalah objek, dimana objek 3D memiliki beberapa jenis, salah satu yang selalu digunakan adalah objek manusia. Objek manusia memiliki tingkat kesulitan yang tinggi, terutama pada bagian rambut. Setiap pembuatan model rambut memiliki proses yang berbeda-beda. Tahap kedua adalah rigging, rigging biasa disebut tulang animasi yang berfungsi menggerakkan objek suatu animasi. Berdasarkan hal tersebut penelitian ini menjelaskan proses implementasi rigging pada beberapa model rambut 3D dan pola dasar untuk menentukan jenis rambut yang akan dibuat. Pengimplementasian model ini, menggunakan pendekatan model rigging antara objek dan animator sehingga dapat menghasilkan karya animasi 3D dengan baik.
\end{abstract}

Kata Kunci: Animasi 3D, Modeling, Rigging

\section{ABSTRACT}

$3 D$ animation is an art to be able to create and move $3 D$ objects, so that it can produce a movement in accordance with the wishes of the maker. In making the animation, 3D objet and rigging are needed. The stages of program implementation are: The first stage is an object, where 3D objects choose several types, one of which is always used is a human object. Human objects have a high level of difficulty, especially the hair. Each hairdo making chooses a different surgical process. The second stage is rigging, regular rigging is likened to an animation bone that functions to move an animation object. Based on this, this research describes the process of implementing rigging in several $3 D$ hairstyles and basic patterns to determine the type of hair to be made. The implementation of this model uses a rigging model approach between the object and the animator so that it can produce $3 D$ animation works well.

Keywords: 3D Animation, Modeling, Rigging

\section{PENDAHULUAN}

Sekarang ini animasi bukanlah sebuah film yang dinikmati, tapi animasi juga biasanya digunakan beberapa hal, baik digunakan untuk hiburan sampai digunakan untuk media informasi dan pembelajaran. Salah satu penelitian yang mengangkat animasi sebagai media pembelajaran untuk mempermudah proses pembelajaran (Cahyani, 2020), proses penelitian ini sejalan dengan teori yang menyatakan melihat dan mendengarkan memberikan respon sebanyak $50 \%$ dari pada cuma membaca dari sebuah buka sekitar 10\% 
yang dipaparkan dari Magnesen (Dryden \& vos, 1999).

Animasi yang banyak digunakan pada saat ini adalah animasi 3D, pembuatan animasi ini membutuhkan objek 3D untuk pengelolaannya. Objek 3D tersebut biasa digunakan untuk main carakter ataupun sebagai background. Objek yang sering digunakan adalah objek manusia. Dalam proses pembuatan objek manusia, hal yang paling susah dilakukan adalah pada bagian rambutnya. Dimana bagian tersebut memiliki berbagai proses dan kendala dalam pembuatannya, baik dari segi bentuknya maupun proses gerak rambut tersebut. Dari penjelasan tersebut penelitian ini bertujuan untuk mengetahui bagaimana proses pembuatannya hingga proses geraknya.

Dalam penelitian (Olszewski et al., 2020), menjelaskan bahwa dalam proses 3D hal yang paling penting adalah bagian basic, bacis merupakan dasar atau tempat di mana proses itu di buat. Memahami basic sebuah objek terbuat memungkin pemilihan rekomendasi bentuk sebuah objek rambut yang akan dibuat (Saito et al., 2018), dalam penelitian memberikan gambaran referensi bentuk bentuk rambut dari hasil penelitiannya tersebut dimana hasil tersebut tidak membantu dalam bentuknya saja tapi membantu juga dalam proses pergerakannya yang akan datang.

Proses gerak pada sebuah objek harus memperhatikan lingkungan dan sebuah gerak objek tersebut, salah satu contoh animasi yang tidak memperhatikan faktor lingkungan dapat dilihat pada penelitian (Shen, 2020). Dalam animasi itu, gerakan rambutnya tidak bergerak sama sekali yang menyebabkan hal itu terlihat kurang baik. Bisa dilihat bahwa hal sekecil itu memerlukan sebuah tindakan tersendiri untuk menghasilkan sebuah gerakan yang mulus dan membuat nilai tambah pada sebuah animasi.

Dari latar belakang tersebut penelitian ini akan meneliti objek 3D pada rambut baik itu pada basic objek sampai gerakannya.

\section{LANDASAN TEORI}

Dengan menggunakan metode gravitasi (Iben et al., 2019) yang pernah dibawakan oleh penelitian sebelumnya mengenai sebuah gerakan animasi. Penelitian ini akan melakukan pendekatan yang sama untuk menghasilkan hasil yang sesuai. Dalam penelitian tersebut, menggunakan pendekatan untuk mendapatkan data mengenai dampak metode tersebut.

Penelitian yang membahas mengenai system rigging (Science \& Science, 2020) dan proses kerja rigging dapat menjadi dasar untuk membuat animasi gerak rambut. Penelitian yang membahas mengenai rigging dalam manusia (M.Fahrudin, 2020), penelitian tersebut menjelaskan bagaimana sebuah gerakan manusia bagian kepala dapat bergerak berirama dengan gerakan rambut.

\section{METODE PENELITIAN}

Penelitian ini menggunakan metode kuantitatif yang bersifat eksperimen. Dimana proses ini terdiri dari pembentukan objek 3D, basic pola rambut, jenis rambut dan rigging rambut.

Dalam buku (Setiawan, A., P. Ulhaq, M., M., 2012) menjelaskan prinsip animasi, dalam prinsip tersebut di singgung lengkungan dan kelenturan. Bisa dilihat pada prinsip kelengkungan harus 
memahami konsep metode gravitasi di mana sebuah objek harus terikat pada sebuah aturan alam. Pada gambar 1 dapat terlihat posisi rambut yang sesuai dengan hukum gravitasi.

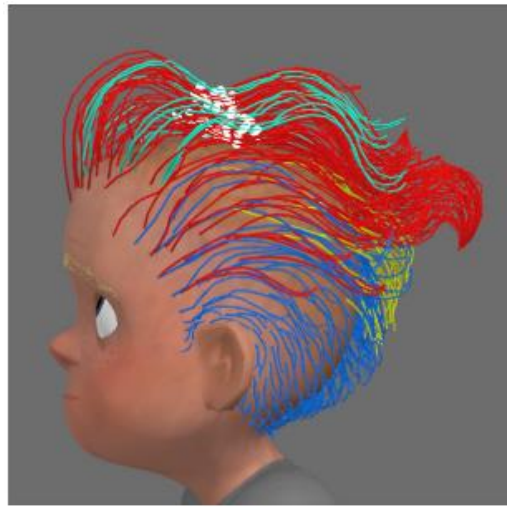

Gambar 1. Efek rambut [5].

Adapun prinsip kelenturan, penerapan kelenturan pada figur atau benda hidup memberikan enhancement sekaligus efek dinamis terhadap gerakan/action tertentu. Pada prinsip ini, peranan yang disinggung adalah rigging, dimana pada proses dari implementasi rigging akan mempengaruhi kelenturan sebuah objek. Bisa dilihat pada gambar 2 dimana saat implementasi rigging dilakukan dengan keadaan salah yang akan menghasilkan kelenturan yang kurang memuaskan.

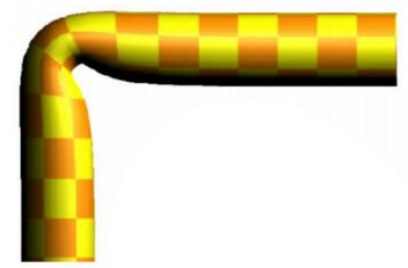

Gambar 2. Implementasi rigging

\section{HASIL DAN PEMBAHASAN}

\subsection{Modeling}

Model yang akan dibuat adalah model 3D manusia berfokus pada bagian kepala. Dalam pembuatan animasi 3D untuk membuat objek manusia biasanya menggunakan 2 cara yaitu sculpting dan modeling. Sculpting adalah metode memahat sebuah objek hingga membuat objek yang sesuai denga model yang diinginkan oleh pembuat, sedangkan modeling memodifikasi objek untuk menghasilkan sebuah modifikasi objek 3D. Pada gambar 3 dapat dilihat objek kepala yang dibuat atau digunakan.

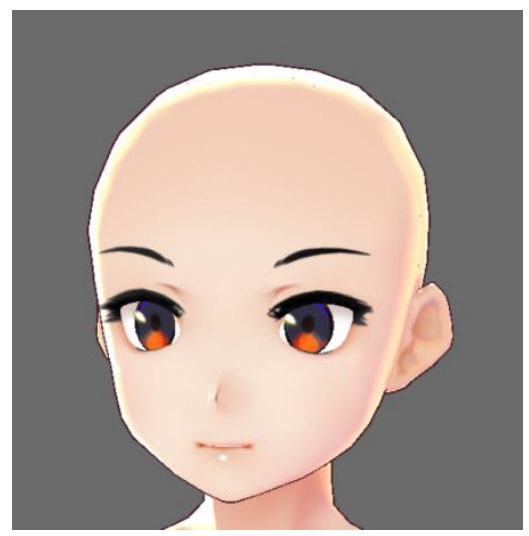

Gambar 3. Model 3D

\subsection{Basic Pola}

Pada pola atau susunan kepala pada bagian depan biasanya memiliki pola ke atas, datar dan juga lancip ke depan, seperti pada gambar 4. Sedangkan pada bagian belakang dengan pola lurus dan lancip seperti pada gambar 5 .

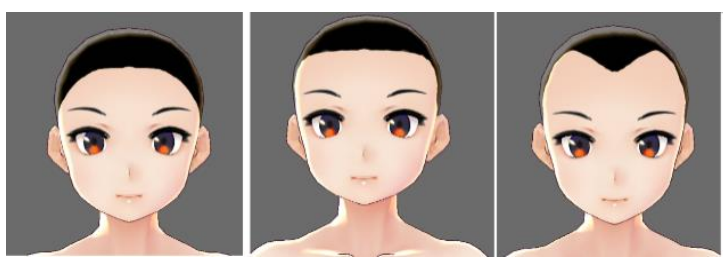

Gambar 5. Dasar pola rambut depan

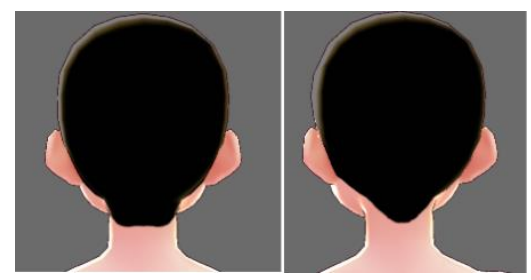

Gambar 5. Dasar pola rambut dari belakang 
Pembuatan pola ini berguna untuk penentuan model rambut, misalkan pola lancip maka model rambut akan menonjol pada bagian poni yang panjang dan lurus ke tengah dan jika pola rambut datar maka akan memiliki rambut poni yang lurus seperti gambar 6 berikut ini.

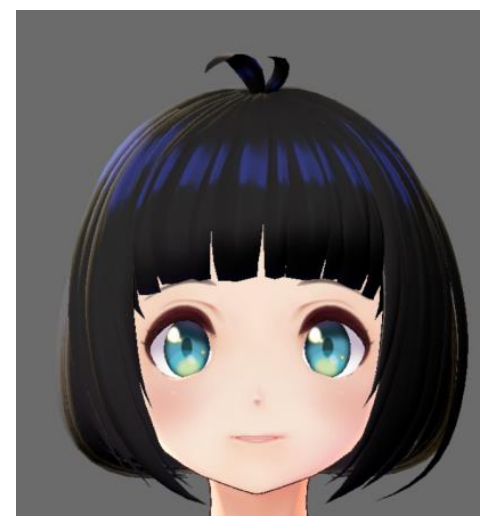

Gambar 6. Contoh model rambut

\subsection{Jenis Rambut}

Dalam animasi 3D, objek rambut memiliki beberapa jenis diantaranya rambut 2D, 3D, dan semi realistic. Jenis rambut ini akan menghasilkan model rambut yang memiliki keunikan tersendiri. Jenis rambut semi realistic dapat dilihat pada gambar 7 .
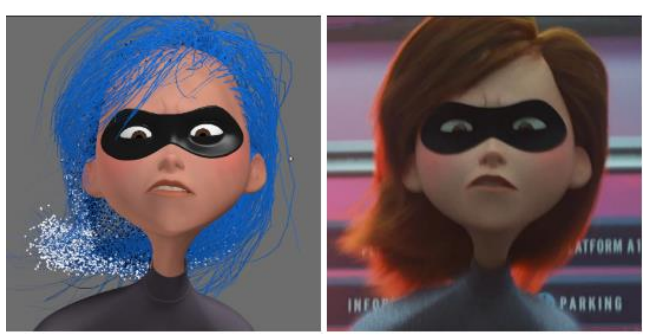

Gambar 7. Contoh rambut semi realistik

Salah satu contoh rambut 3D dapat dilihat pada gambar 8. Model rambut tersebut memiliki karasteristik volume yang rambut terlihat berisi.

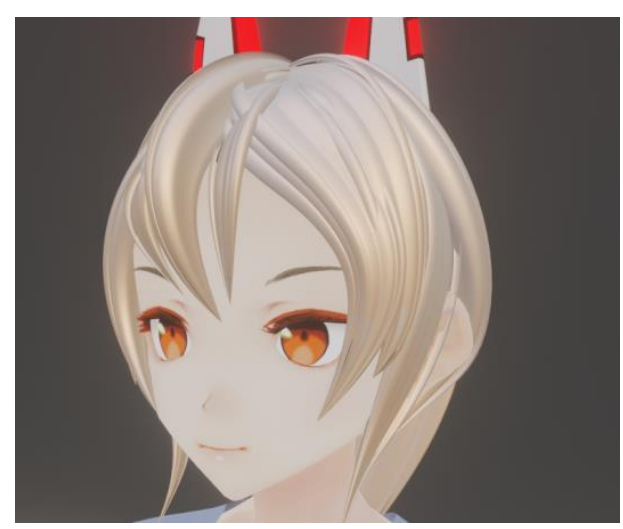

Gambar 8. Contoh model rambut 3D

\subsection{Rigging Rambut}

Pemberian rigging pada rambut harus memperhatikan posisi peletannya, harus disesuaikan dengan bentuk rambut yang ada. Pada gambar 9 dan gambar 10 merupakan proses pembuatan rigging rambut yang bergerak

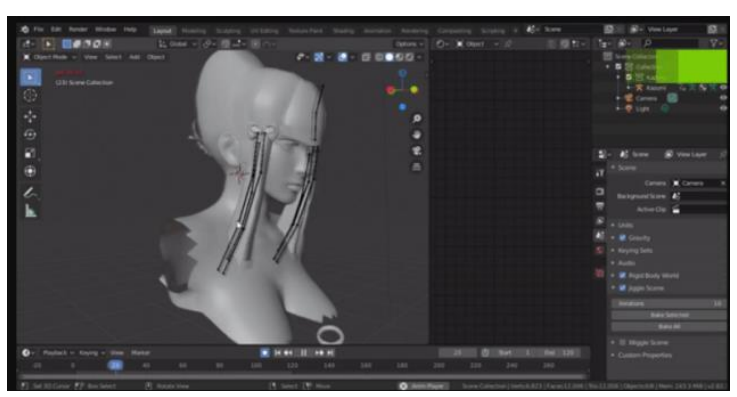

Gambar 9. Gerakan rambut ke belakang

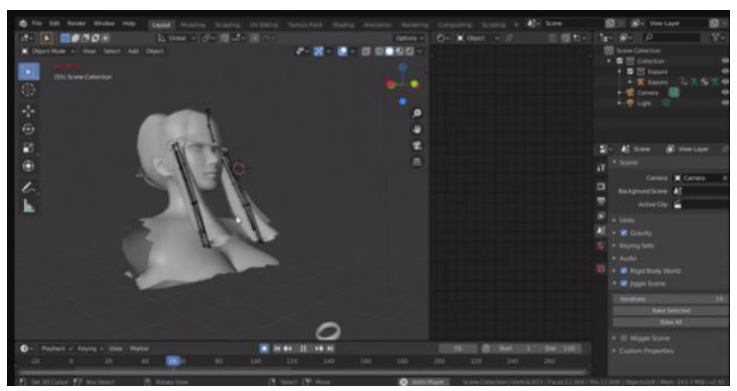

Gambar 10. Gerakan rambut ke depan

Dalam rigging dikenal dengan zona aktif yang merupakan zona penentuan kesensitifikan rambut. Klasifikasi zona di bagi dalam beberapa zona, yaitu zona merah maka objek tersebut akan sangat aktif bergerak sedangkan zona biru maka tidak ada proses gerak dan zona kuning dan 
hijau mengisaratkan pergerakan yang tidak terlalu banyak. Klasifikasi warna zona dapat dilihat pada gambar 11.

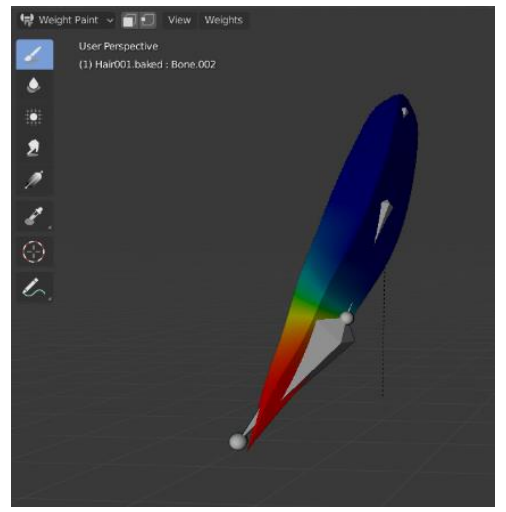

Gambar 11. Weight paint

\section{KESIMPULAN PENELITIAN}

Proses pembuatan animasi rambut memberikan nilai tambah yang membuat penikmat merasa senang melihatnya. Pembuatan animasi tersebut membutuhkan beberapa tahap seperti pembuatan objek, pola dan sampai implementasi rigging. Implementasi ragging bukanlah hal yang mudah dimana harus memahami konsep hukum alam untuk menciptakan sebuah gerakan yang natural. Peletakan rigging juga salah satu kunci dalam pembuatannya di mana tahap itu akan menentukan titik kesensitifan sebuah objek yang ada.

\section{UCAPAN TERIMA KASIH}

Dengan pesan ini penulis mengucapkan terimakasih kepada pembimbing dari UNIVERSITAS AMIKOM yang telah memberikan ilmu dan materi untuk dapat menghasilkan sebuah karya tulis ilmiah ini.

Saya ucapkan terimakasih kepada pihak STMIK AKBA yang telah memberikan jasa atas publikasi karya ilmiah ini.

Dan tidak lupa juga ucapkan terima kasih kepada keluarga dan teman teman saya, yang telah memberikan dorongan, bantuan, dan doa dalam proses pembuatan karya ilmiah ini.

\section{DAFTAR PUSTAKA}

Cahyani, I. R. (2020). Pemanfaatan Media Animasi 3 Dimensi. 5, 57-68.

Iben, H., Brooks, J., \& Bolwyn, C. (2019). Holding the shape in hair simulation. ACM SIGGRAPH 2019 Talks, SIGGRAPH 2019, 2-3. https://doi.org/10.1145/3306307.3328 166

M.Fahrudin. (2020). Simulasi Gerak Manusia Pada Animasi 3D. UNIVERSITAS ISLAM NEGERI MAULANA MALIK IBRAHIM MALANG.

Olszewski, K., Ceylan, D., Xing, J., Echevarria, J., Chen, Z., Chen, W., \& $\mathrm{Li}, \mathrm{H}$. (2020). Intuitive, interactive beard and hair synthesis with generative models. Proceedings of the IEEE Computer Society Conference on Computer Vision and Pattern Recognition, 7444-7454. https://doi.org/10.1109/CVPR42600.2 020.00747

Saito, S., Hu, L., Ma, C., Ibayashi, H., Luo, L., \& Li, H. (2018). 3D hair synthesis using volumetric variational autoencoders. SIGGRAPH Asia 2018 Technical Papers, SIGGRAPH Asia 2018, 37(6). https://doi.org/10.1145/3272127.3275 019

Science, C., \& Science, C. (2020). Deep Rigging: Automatic Character Skinning for Animation. 2019.

Setiawan, A., P. Ulhaq, M., M., Z. (2012). Simulasi Digital: Animasi.

Shen, H. (2020). Design and Production of 3D Animation Short Film " Memories of the Post-80s " Design and Production of 3D Animation Short Film " Memories of the Post-80s " Rochester Institute of Technology. 